\title{
Effect of Different Specifications of Symbicort Turbuhaler on the Treatment of Patients with Bronchial Asthma
}

\author{
ZHI HE ZHOU, D. WANG, LIN JUAN TIAN, Y. G. WEI AND Y. P. WU*
}

Department of Pneumology, The First People's Hospital of Lanzhou, No. 1 Wujiayuan West Street, Qilihe District, Lanzhou, Gansu 730050, China

Zhou et al.: Symbicort Turbuhaler Efficacy on the Treatment of Bronchial Asthma Patients

To investigate the efficacy of different sizes of symbicort turbuhaler in the treatment of bronchial asthma and its effect on eosinophils. 138 patients diagnosed with bronchial asthma treated in our hospital from January 2019 to January 2020 were selected and randomly divided into high dose (n=69) and low dose groups $(n=69)$ and both groups were treated with different doses of Symbicortol on top of the conventional treatment regimen, in which the low-dose group was $80 \mu \mathrm{g} / 4.5 \mu \mathrm{g} / \mathrm{inh}$ alation: 1 inhalation/inhalation, twice a day, for $8 \mathrm{w}$. The high dose was $160 \mu \mathrm{g} / 4.5 \mu \mathrm{g} / \mathrm{inh}$ alation: 1 inhalation/inhalation, twice a day, for $8 \mathrm{w}$. The results showed that after treatment, arterial partial pressure of oxygen decreased and arterial partial pressure of carbon dioxide and blood oxygen saturation increased in both groups compared with those before treatment, with more obvious changes in the high dose group $(p<0.01)$. After treatment, forced expiratory volume, forced expiratory volume/forced vital capacity and peak expiratory flow levels were significantly increased $(\mathbf{p}<\mathbf{0 . 0 5})$, while peak expiratory flow rate percentage levels were significantly decreased $(p<0.05)$ and the indexes in the high dose group were changes more obviously $(p<0.01)$. The levels of eotaxin-2, C-C Motif Chemokine Receptor 3 and Mucin-5ACCurated were significantly lower after treatment $(p<0.05)$ and the above indexes were significantly lower in the high dose group $(p<0.01)$. The total clinical efficiency of the high dose group was $92.75 \%$, which was significantly higher than that of the low dose group (79.71\%) and the difference was statistically significant. There was no significant difference in the incidence rate between the two groups $(p>0.05)$. In the treatment of bronchial asthma, different sizes of symbicort turbuhaler are able to control the disease, promote rapid recovery and improve the respiratory status of patients with an ideal safety.

Key words: Bronchial asthma, symbicort turbuhaler, eosinophil, clinical efficacy

Bronchial asthma is a common disease of respiratory system, which is a chronic airway inflammatory disease mainly composed of eosinophils (EOS), mast cells, T lymphocytes and other cells. Most patients have dyspnea, cough and other symptoms and are prone to recurrent attacks ${ }^{[1,2]}$. In recent years, with the increasing environmental pollution and haze, the incidence rate of bronchial asthma is increasing year by year. Once the diagnosis of asthma is established, regular control treatment should be started as soon as possible, which is the key to achieve the best treatment effect. At present, because of economic problems, worry about hormone side effects, lack of understanding of standardized treatment of asthma and other reasons, many bronchial patients ignore maintenance treatment, resulting in poor control of asthma and repeated attacks. Therefore, to explore an effective long-term treatment for acute bronchial asthma. At present, it is considered that the main principle for patients with bronchial asthma in remission stage is to maintain clinical control of symptoms and prevent recurrence ${ }^{[3]}$. The treatment of bronchial asthma in remission stage is mainly the combination of hormone and $\beta$ receptor agonist $\mathrm{t}^{[4]}$, which can partially relieve respiratory symptoms, reduce the degree of airflow limitation and prevent acute attack. Symbicort turbuhaler is a compound dosage form of Glucocorticoid (budesonide) and longacting $\beta 2$ receptor agonist (formoterol), which has good curative effect on chronic obstructive pulmonary disease $^{[5]}$. However, there is no report about the

*Address for correspondence

E-mail: wyp1975362@163.com 
therapeutic effect of different specifications of symbicort turbuhaler on bronchial asthma. Therefore, the main purpose of this study is to explore the efficacy of different specifications of symbicort turbuhaler in the treatment of bronchial asthma and its effect on eosinophils. A total of 138 patients with bronchial asthma in our hospital from January 2019 to January 2020 were selected and randomly divided into high dose group $(n=69)$ and low dose group $(n=69)$. In the low dose group, there were 33 males and 36 females, ranging in age from 32 to $56 \mathrm{y}$. The average age was $(46.48 \pm 3.53) \mathrm{y}$ and the course of disease ranged from 2 to $9 \mathrm{y}$ and the average course of disease was $(6.3 \pm 2.1)$ y. In the high dose group, there were 34 males and 35 females and the range of age was 33 to $55 \mathrm{y}$ and the average age was $(45.89 \pm 3.17)$ y. The course of disease ranged from 3 to $9 \mathrm{y}$ and the average course of disease was $(6.4 \pm 1.9)$ y. There was no significant difference in the general information of patients, including age, gender, course of disease, etc. $(p>0.05)$. The study was approved by the hospital ethics committee and informed consent was obtained from patients and the consent form of educated youth was signed. Before the treatment of symbicort turbuhaler, the two groups of patients need to be treated by conventional methods, including: anti infection treatment, oxygen therapy. The low dose group was treated with $80 \mu \mathrm{g} / 4.5 \mu \mathrm{g} /$ inhalation of symbicort turbuhaler twice a day; the high dose group was treated with $160 \mu \mathrm{g} / 4.5 \mu \mathrm{g} /$ inhalation of symbicort turbuhaler twice a day; the treatment cycle lasted for 8 w. The number of eosinophils in peripheral venous blood and the level of mucus secretory factor were measured before and after treatment. $2 \mathrm{ml}$ of peripheral venous blood was extracted from the patient with anticoagulant tube and the blood cells were classified and counted on the blood cell analyzer. The levels of eotaxin-2 (CCL24), C-C Motif Chemokine Receptor 3 (CCR3) and Mucin-5ACCurated (MUC5AC) in sputum were detected by immunoturbidimetry. The pulmonary function before and after treatment in each group was compared. The forced expiratory volume in the first second (FEV1), forced vital capacity (FVC) and the predicted forced expiratory volume in the first second (FEV1 \%) were measured by pulmonary function analyzer (Germany yerger company). Evaluation and comparison of treatment effect. Remarkable effect: after treatment, the symptoms of dyspnea and asthma disappeared, the physical signs returned to normal and the lung function test showed that they returned to normal; effective: after treatment, the above symptoms improved and the lung wheezing sound weakened; ineffective: the symptoms did not meet the above standards, or even worsened and the total effective rate $=($ number of markedly effective cases + number of effective cases) $\times$ total cases $\times 100 \%{ }^{[3]}$; The incidence of adverse reactions, including mild headache, gastrointestinal dysfunction, liver dysfunction; Blood gas indexes, including arterial partial pressure of oxygen $\left(\mathrm{PaO}_{2}\right)$, arterial partial pressure of carbon dioxide $\left(\mathrm{PaCO}_{2}\right)$ and blood oxygen saturation $(\mathrm{SaO})$, were measured and compared $1 \mathrm{~d}$ before treatment and $8 \mathrm{w}$ after treatment. Statistical package for the social sciences (SPSS) 20.0 statistical software was used for data analysis. The measurement data were expressed as $\mathrm{x} \pm \mathrm{S}$ and the comparison of the rates was performed by $\chi 2$ test. The comparison of samples between groups and before and after treatment was performed by test. $* p<0.05, \quad * * p<0.01 \quad$ were considered statistically significant. Compared with the low dose group, there was no significant difference in $\mathrm{PaO}_{2}, \mathrm{PaCO}_{2}$ and $\mathrm{SaO}_{2}$ between the two groups before treatment $(\mathrm{p}>0.05)$. After treatment, $\mathrm{PaO}_{2}$ of the two groups was lower than before treatment, $\mathrm{PaCO}_{2}$ and $\mathrm{SaO}_{2}$ were higher than before treatment. Compared with the low dose group, the change of high dose group was more obviously $(\mathrm{p}<0.01)$, as shown in Table 1. Compared with the low dose group, there was no significant difference in the changes of p-peripheral blood eosinophils between the two groups before treatment ( $p>0.05)$. After treatment, the levels of CCL24, CCR3 and MUC5AC in the two groups were significantly decreased $(p<0.05)$ and the above indexes in the high dose group were significantly lower than those in the low dose group $(p<0.01)$, as shown in Table 2. After treatment, the levels of FEV1, FEV1/FVC and peak expiratory flow (PEF) in the two groups was significantly increased $(\mathrm{p}<0.05)$. The peak expiratory flow rate (PEFR) percentage level was significantly decreased $(p<0.05)$ and the above indexes in the high dose group were significantly better $(p<0.01)$, as shown in Table 3. The total effective rate of high dose group was $92.75 \%$, which was significantly higher than $79.71 \%$ of low dose group $(\mathrm{p}<0.05)$, as shown in Table 4. There was no significant difference in the incidence of adverse reactions between the high dose group and the control group ( $\mathrm{p}>0.05)$, as shown in Table 5. Bronchial asthma is a chronic inflammatory disease of the airway ${ }^{[6]}$ and its specific pathogenesis has not been fully elucidated. Studies ${ }^{[7]}$ have shown that its occurrence and development are related to non-specific irritants, allergy, climate, spirit, genetics and other factors. Timely and effective treatment can reduce or avoid the occurrence of airway remodeling and 
irreversible airway stenosis in patients with bronchial asthma. Untimely treatment can lead to pulmonary edema, airway thickening and stenosis. In severe cases, obstructive ventilation dysfunction and respiratory failure may occur, directly endangering the safety of patients. Previous studies have shown that eosinophil infiltration exists in all aspects of bronchial asthma airway pathological changes and is the main effector cell leading to persistent and acute exacerbation of chronic airway inflammation ${ }^{[8-10]}$. CCL24, CCR3 and MUC5AC are considered as key indicators of eosinophil infiltration and asthma severity. Among them, CCR3 receptor mainly stimulates eosinophil phase airway chemotaxis by binding with CCL24 and then blocks its activation process $^{[9]}$; MUC5AC is a kind of mucin, which is also the main component of airway mucus. In remission stage of bronchial asthma, local chronic inflammation and acute attack aggravate airway damage and the number of goblet cells and glands increases, which is considered to be an important reason for the increase of MUC5AC secretion ${ }^{[11]}$. This study showed that the changes of eosinophils in peripheral blood of the two groups after treatment were lower than those before treatment. Compared with the low dose group, the changes in the high dose group were more obvious, but the difference was not statistically significant $(p<0.05)$. The levels of CCL24, CCR3 and MUC5AC in the two groups were significantly decreased after treatment $(\mathrm{p}<0.05)$ and the above indexes in the high dose group were significantly lower than those in the low dose group $(\mathrm{p}<0.05)$, indicating that high dose symbicort can more effectively inhibit the proliferation and growth of eosinophils and inhibit the overexpression of related factors of eosinophil infiltration. symbicort turbuhaler can improve the pathophysiological process of airway remodeling by reducing the secretion of mucus factors, which has a certain intervention effect on airway remodeling. Symbicort turbuhaler is a compound mixture of glucocorticoid and long-acting $\beta 2$ receptor agonist. Studies have shown that ${ }^{[12]}, \beta 2$ receptor agonist can be used as a drug for the treatment of asthma, which can dilate the bronchus, relieve the airway spasm of patients and the efficacy lasts for a long time, with good clinical effect. And the use of inhaler treatment, less harm to patients, no pain of oral medication, has a good acceptance. The results of this study show that the clinical treatment effect of the high dose group is better than that of the low dose group and the improvement of blood gas index after treatment is also better than that of the low dose group and it does not increase the incidence of adverse reactions of patients, which indicates that symbicort turbuhaler can appropriately increase the dose to obtain better curative effect in the treatment of bronchial asthma. The possible reason is that formoterol is a highly selective longacting $\beta 2$ receptor agonist, which mainly acts on the $\beta 2$ receptor on airway smooth muscle cells and then activates adenylate cyclase to produce Cyclic adenosine monophosphate (cAMP), thus relaxing airway smooth muscle relaxation and relaxing airway. Combined application of budesonide and formoterol can produce complementary coordination effect. Budesonide can increase the transcription of $\beta 2$ receptor gene in lung tissue cell membrane, increase the synthesis of $\beta 2$ receptor in airway mucosa, improve the tolerance and desensitization of $\beta 2$ receptor and then enhance the bronchodilation effect of formotero ${ }^{[11,13]}$. In addition, formoterol can activate protein kinase through cytokinin, phosphorylate glucocorticoid receptor, activate glucocorticoid receptor, make it more sensitive to budesonide and increase its efficacy ${ }^{[14-16]}$. The effect of inhaled corticosteroid (ICS)/long-acting $\beta$-agonist (LABA) compound preparation is equal to or even better than that of double dose ICS, which can increase the compliance of patients and reduce the adverse reactions of large dose ICS. In conclusion, in the treatment of bronchial asthma, different specifications of symbicort can control the disease, promote the rapid recovery of the disease and improve the respiratory state of patients.

TABLE 1: COMPARISON OF BLOOD GAS INDEXES BETWEEN THE TWO GROUPS

\begin{tabular}{|c|c|c|c|c|c|c|c|}
\hline \multirow{2}{*}{ Group } & \multirow{2}{*}{$\mathbf{N}$} & \multicolumn{2}{|c|}{$\mathrm{PaO}_{2}(\mathrm{mmHg})$} & \multicolumn{2}{|c|}{$\mathrm{PaCO}_{2}(\mathrm{mmHg})$} & \multicolumn{2}{|c|}{$\mathrm{SaO}_{2}(\%)$} \\
\hline & & $\begin{array}{c}\text { Before } \\
\text { treatment }\end{array}$ & $\begin{array}{c}\text { After } \\
\text { treatment }\end{array}$ & $\begin{array}{c}\text { Before } \\
\text { treatment }\end{array}$ & $\begin{array}{c}\text { After } \\
\text { treatment }\end{array}$ & $\begin{array}{c}\text { Before } \\
\text { treatment }\end{array}$ & $\begin{array}{c}\text { After } \\
\text { treatment }\end{array}$ \\
\hline Low dose & 69 & $51.21 \pm 4.22$ & $45.23 \pm 4.5^{*}$ & $62.31 \pm 6.54$ & $74.66 \pm 6.1^{*}$ & $82.31 \pm 4.57$ & $91.47 \pm 6.9^{*}$ \\
\hline High dose & 69 & $51.13 \pm 4.07$ & $38.44 \pm 4.3^{* *}$ & $62.14 \pm 4.87$ & $84.26 \pm 5.3^{* *}$ & $82.08 \pm 4.76$ & $95.88 \pm 6.1^{* *}$ \\
\hline
\end{tabular}

Note: Compared with before treatment: ${ }^{*} \mathrm{p}<0.05,{ }^{* *} \mathrm{p}<0.01$ 
TABLE 2: CHANGES OF EOSINOPHIL NUMBER AND SECRETION FACTOR LEVELS IN PERIPHERAL VENOUS BLOOD BEFORE AND AFTER TREATMENT

\begin{tabular}{|c|c|c|c|c|c|c|c|}
\hline \multirow{2}{*}{ Group } & \multirow{2}{*}{$\mathbf{N}$} & \multicolumn{2}{|c|}{ CCL24/( $\mu \mathrm{g} / \mathrm{L})$} & \multicolumn{2}{|c|}{ CCR3/(ng/L) } & \multicolumn{2}{|c|}{ Muc5ac/( $\mu \mathrm{g} / \mathrm{L})$} \\
\hline & & $\begin{array}{c}\text { Before } \\
\text { treatment }\end{array}$ & $\begin{array}{c}\text { After } \\
\text { treatment }\end{array}$ & $\begin{array}{c}\text { Before } \\
\text { treatment }\end{array}$ & $\begin{array}{c}\text { After } \\
\text { treatment }\end{array}$ & $\begin{array}{c}\text { Before } \\
\text { treatment }\end{array}$ & $\begin{array}{c}\text { After } \\
\text { treatment }\end{array}$ \\
\hline Low dose & 69 & $1.47 \pm 0.38$ & $1.16 \pm 0.24^{*}$ & $46.72 \pm 9.33$ & $18.47 \pm 2.48^{*}$ & $259.31 \pm 37.78$ & $182.21 \pm 20.56^{*}$ \\
\hline High dose & 69 & $1.52 \pm 0.34$ & $0.76 \pm 0.13^{* *}$ & $45.49 \pm 9.28$ & $7.93 \pm 1.27^{* *}$ & $257.67 \pm 32.58$ & $79.35 \pm 10.4^{* *}$ \\
\hline
\end{tabular}

Note: Compared with before treatment: ${ }^{*} \mathrm{p}<0.05,{ }^{* *} \mathrm{p}<0.01$

TABLE 3: CHANGES OF LUNG FUNCTION BEFORE AND AFTER TREATMENT IN TWO GROUPSb

\begin{tabular}{lccccccccc}
\hline & & \multicolumn{2}{c}{ FEV1 (\%) } & \multicolumn{2}{c}{ FEV1/FVC (\%) } & \multicolumn{2}{c}{ PEF (L/s) } & \multicolumn{2}{c}{ PEFR \% } \\
\cline { 2 - 9 } Group & $\mathrm{N}$ & $\begin{array}{c}\text { Before } \\
\text { treatment }\end{array}$ & $\begin{array}{c}\text { After } \\
\text { treatment }\end{array}$ & $\begin{array}{c}\text { Before } \\
\text { treatment }\end{array}$ & $\begin{array}{c}\text { After } \\
\text { treatment }\end{array}$ & $\begin{array}{c}\text { Before } \\
\text { treatment }\end{array}$ & $\begin{array}{c}\text { After } \\
\text { treatment }\end{array}$ & $\begin{array}{c}\text { Before } \\
\text { treatment }\end{array}$ & $\begin{array}{c}\text { After } \\
\text { treatment }\end{array}$ \\
\hline Low dose & 69 & $60.75 \pm 8.28$ & $79.25 \pm 8.75^{*}$ & $32.77 \pm 7.38$ & $45.45 \pm 5.12^{*}$ & $4.47 \pm 0.37$ & $6.73 \pm 0.46^{*}$ & $32.98 \pm 5.09$ & $21.09 \pm 1.58^{*}$ \\
High dose & 69 & $61.55 \pm 10.45$ & $88.52 \pm 6.28^{* *}$ & $31.68 \pm 6.21$ & $55.85 \pm 3.36^{* *}$ & $4.52 \pm 0.33$ & $8.83 \pm 0.52^{* *}$ & $32.74 \pm 5.19$ & $7.23 \pm 1.16^{* *}$ \\
\hline
\end{tabular}

Note: Compared with before treatment: ${ }^{*} p<0.05,{ }^{* *} p<0.01$

TABLE 4: EVALUATION AND COMPARISON OF THERAPEUTIC EFFECT

\begin{tabular}{lccccc}
\hline Group & N & Markedly effective & Effective & Ineffective & Total effective rate \\
\hline Low dose & 69 & $18(26.09)$ & $37(53.62)$ & $14(20.29)$ & $79.71 \%$ \\
High dose & 69 & $25(36.23)$ & $39(56.52)$ & $5(7.25)$ & $92.75 \% \#$ \\
\hline
\end{tabular}

Note: Compared with low dose group: $\# \mathrm{p}<0.05$

TABLE 5: COMPARISON OF THE INCIDENCE OF ADVERSE REACTIONS BETWEEN THE TWO GROUPS

\begin{tabular}{lccccc}
\hline Group & N & Mild headache & $\begin{array}{c}\text { Gastrointestinal } \\
\text { dysfunction }\end{array}$ & $\begin{array}{c}\text { Abnormal liver } \\
\text { function }\end{array}$ & $\begin{array}{c}\text { Total adverse } \\
\text { reaction rate }\end{array}$ \\
\hline Low dose & 69 & $1(1.45)$ & $2(2.90)$ & $1(1.45)$ & $5.80 \%$ \\
High dose & 69 & $2(2.90)$ & $3(4.35)$ & $1(1.45)$ & $8.70 \%$ \\
\hline
\end{tabular}

\section{Acknowledgement:}

This work was supported by The First People's Hospital of Lanzhou.

\section{Conflicts of interest:}

The authors report no conflicts of interest.

\section{REFERENCES}

1. Ducharme FM, Chroinin MN, Greenstone I, Lasserson TJ. Addition of long-acting beta2-agonists to inhaled steroids versus higher dose inhaled steroids in adults and children with persistent asthma. Cochrane Database Syst Rev 2010(4):D5533.

2. Bateman ED, Reddel HK, Eriksson G, Peterson S, Östlund $\mathrm{O}$, Sears MR, et al. Overall asthma control: the relationship between current control and future risk. J Allergy Clin Immunol 2010;125(3):600-8.

3. D'Amato M, Vitale C, Molino A, Lanza M, D'Amato G. Anticholinergic drugs in asthma therapy. Curr Opin Pulm Med 2017;23(1):103-8.
4. Kirkland SW, Vandenberghe C, Voaklander B, Nikel T, Campbell S, Rowe BH. Combined inhaled beta-agonist and anticholinergic agents for emergency management in adults with asthma. Cochrane Database Syst Rev 2017(1):D1284.

5. Song WJ, Kang MG, Chang YS, Cho SH. Epidemiology of adult asthma in Asia: toward a better understanding. Asia Pac Allergy 2014;4(2):75-85.

6. Wang X, Wu K, Keeler SP, Mao D, Agapov EV, Zhang Y, et al. TLR3-Activated Monocyte-Derived Dendritic Cells Trigger Progression from Acute Viral Infection to Chronic Disease in the Lung. J Immunol 2021;206(6):1297-314.

7. Rabe KF, Vermeire PA, Soriano JB, Maier WC. Clinical management of asthma in 1999: the Asthma Insights and Reality in Europe (AIRE) study. Eur Respir J 2000;16(5):8027.

8. Neffen H, Fritscher C, Cuevas Schacht F, Levy G, Chiarella P, Soriano JB, et al. Asthma control in Latin America: the asthma insights and reality in Latin America (AIRLA) survey. Rev panam salud pública 2005;17:191-7.

9. Wong GW, Kwon N, Hong JG, Hsu JY, Gunasekera KD. Pediatric asthma control in Asia: Phase 2 of the Asthma Insights and Reality in Asia-Pacific (AIRIAP 2) survey. Allergy 2013;68(4):524-30. 
10. Su N, Lin J, Chen P, Li J, Wu C, Yin K, et al. Evaluation of asthma control and patient's perception of asthma: findings and analysis of a nationwide questionnaire-based survey in China. J Asthma 2013;50(8):861-70.

11. Becker AB, Abrams EM. Asthma guidelines: the Global Initiative for Asthma in relation to national guidelines. Curr Opin Allergy Clin Immunol 2017;17(2):99-103.

12. Reddel HK, Taylor DR, Bateman ED, Boulet LP, Boushey HA, Busse WW, et al. An official American Thoracic Society/ European Respiratory Society statement: asthma control and exacerbations: standardizing endpoints for clinical asthma trials and clinical practice. Am J Respir Crit Care Med 2009; 180(1):59-99.

13. Chung KF, Wenzel SE, Brozek JL, Bush A, Castro M, Sterk $\mathrm{PJ}$, et al. International ERS/ATS guidelines on definition, evaluation and treatment of severe asthma. Eur Respir J 2014;43(2):343-73.
14. Zhou X, Ding FM, Lin JT, Yin KS. Validity of asthma control test for asthma control assessment in Chinese primary care settings. Chest 2009;135(4):904-10.

15. Zhang XY, Simpson JL, Powell H, Yang IA, Upham JW, Reynolds PN, et al. Full blood count parameters for the detection of asthma inflammatory phenotypes. Clin Exp Allergy 2014;44(9):1137-45.

16. Liang Z, Zhao H, Lv Y. Moderate accuracy of peripheral eosinophil count for predictingeosinophilic phenotype in steroid-naive non-atopic adult asthmatics. Intern Med 2012;51(7):717-22.

This is an open access article distributed under the terms of the Creative Commons Attribution-NonCommercial-ShareAlike 3.0 License, which allows others to remix, tweak, and build upon the work non-commercially, as long as the author is credited and the new creations are licensed under the identical terms

This article was originally published in a special issue,
"Therapeutic Perspectives in Biomedical Research and Pharma-
ceutical Sciences and their Nursing Methods"
Indian J Pharm Sci 2021:83(4)Spl issue "40-44"

